\title{
Paleozoiczne dowody na interakcje między roślinami a stawonogami
}

\author{
Jolanta Muszer ${ }^{1}$, Adrianna Jankowska ${ }^{2}$
}

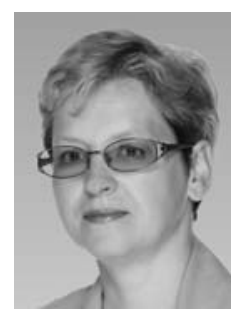

J. Muszer

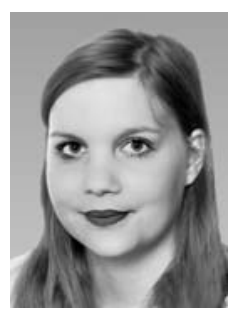

A. Jankowska

Paleozoic evidences of interactions between plants and arthropods. Prz. Geol., 66: 503-509; doi: $10.7306 / 2018.4$.

A b s tra $c t$. The aim of this paper is to summarize the current knowledge about the types of interactions between plants and arthropods and to present their evidences in the Paleozoic fossil record. A new classification of these evidences was proposed based on the function and reaction of plants. This paper presents also their succession, correlated with phases of herbivore arthropod expansion, and phases of evolution of plant-arthropod interactions in the Paleozoic.

Keywords: plant-arthropod interactions, phases of plant expansion, Paleozoic, trace fossils

Kolonizacja lądu przez rośliny i zwierzęta umożliwiła interakcję między nimi, a jej najwcześniejsze dowody znane są z syluru (Edwards i in., 1995; Kenrick, Crane, 1997; Fojcik, 2014). Należą do nich koprolity pochodzące z górnego syluru Walii i Gotlandii, które zawierają wiele zarodników i innych fragmentów roślin, jednoznacznie wskazujących na ich konsumpcję przez zwierzęta (Slater, 2014). Producentami tych koprolitów byli detrytusożercy, dominujący w ówczesnym środowisku lądowym.

Jednym $\mathrm{z}$ najstarszych dobrze zachowanych ekosystemów lądowych jest stanowisko Rhynie w Szkocji (patrz Gensel, Edwards, 2002; Taylor i in., 2009). W martwicach krzemionkowych wieku wczesnodewońskiego bardzo dobrze zachowały się nie tylko skamieniałości (rośliny, glony, grzyby, stawonogi), lecz także dowody na interakcje między gatunkami (m.in. roślinożerność, pasożytnictwo, symbioza; np. Kevan i in., 1975; Taylor i in., 1992, 1995; Habgood i in., 2004).

Najlepiej udokumentowane w zapisie paleontologicznym paleozoiku są jednak interakcje roślin i zwierząt w skałach karbońskich (Taylor, Scott, 1983). Przyczyną tego była intensywna wegetacja w karbonie, która znacznie zwiększyła prawdopodobieństwo zachowania się dowodów interakcji. Drugim czynnikiem było ponadprzeciętne rozpoznanie geologiczne skał tego systemu, ze względu na ekonomiczne znaczenie występujących w nich węgli kamiennych (Taylor, Scott, 1983). Dobry stopień zachowania skamieniałości roślinnych umożliwił obserwowanie na ich powierzchniach śladów interakcji.

Badania nad kopalnymi dowodami na interakcje między roślinami a owadami rozwinęły się znacznie później niż badania paleobotaniczne, paleoentomologiczne czy badania współczesnych interakcji roślin i zwierząt (Labandeira, 2013). Pierwsze prace interpretujące uszkodzenia na powierzchni roślin były nieliczne i często niejednoznaczne (np. Stopes, 1907; Needham i in., 1928; Brues, 1936; Hering, 1951). Dopiero w drugiej połowie XX w. pojawiły się bardziej precyzyjne opisy dowodów interakcji i nastapił znaczący wzrost liczby publikacji poświęconych temu zagadnieniu (np. Huges, Smart, 1967; Carpenter, 1971; Southwood, 1973; Barnard, 1974; Scott, Taylor, 1983; Chaloner i in., 1991) oraz wprowadzono pierwsze klasyfikacje śladów żerowania roślinożerców (np. Vialov, 1968;
Scott $\mathrm{i}$ in., 1992). Na przełomie XX w. i w XXI w. rozszerzono techniki badawcze i analityczne (np. Wilf, 2008; Labandeira, Currano, 2013), a liczba opisanych stanowisk znacznie wzrosła (np. Beck, Labandeira, 1998; Labandeira, 1998, 2006a; Labandeira, Allen, 2007; Slater i in., 2012, Stull i in., 2013; Labandeira i in., 2014; Laaß, Hoff, 2015). W związku z istotnym wzrostem zainteresowania tematem interakcji roślin i stawonogów w paleozoiku, czyli podczas wczesnych etapów kolonizacji lądów, zauważa się potrzebę podsumowania dotychczasowego stanu wiedzy na ten temat oraz ponownej klasyfikacji jej kopalnych dowodów.

\section{TYPY INTERAKCJI I KLASYFIKACJE DOWODÓW NA INTERAKCJE W ZAPISIE KOPALNYM}

Mianem interakcji określamy wzajemne oddziaływanie, w tym przypadku między roślinami a zwierzętami. Współcześnie w przyrodzie, nie tylko pomiędzy gatunkami roślin i zwierząt, ale również pomiędzy gatunkami i populacjami, wyróżniamy oddziaływania antagonistyczne - niekorzystne dla jednej lub obu populacji w tym samym środowisku lub nieantagonistyczne - takie, w wyniku których żadna ze stron nie ponosi szkody na skutek wzajemnych oddziaływań (patrz Weiner, 2003). Do pierwszej kategorii zaliczamy: konkurencję (obaj partnerzy ograniczają się nawzajem), pasożytnictwo (jeden z partnerów otrzymuje zyski kosztem drugiego), drapieżnictwo, do którego zalicza się również roślinożerność (jeden z partnerów zabija i spożywa drugiego) oraz amensalizm (jeden z partnerów, wpływając niekorzystnie na drugiego, nie zyskuje ani nie traci). Natomiast do oddziaływań nieantagonistycznych należą: mutualizm (symbioza obligatoryjna, obustronny zysk wynikający $\mathrm{z}$ interakcji), protokooperacja (nieobligatoryjna pozytywna interakcja dla dwóch stron), komensalizm (jeden z partnerów odnosi zyski, ale bez strat dla drugiego) oraz neutralizm (partnerzy nie wchodzą w bezpośrednie relacje).

Ze względu na rodzaj pokarmu roślinnego spożywanego przez zwierzęta w paleozoiku możemy wyróżnić (Labandeira, 2006b): detrytusożerców (zjadających martwe tkanki roślinne), roślinożerców (zjadających żywe tkanki roślinne) i pyłkożerców (konsumujących spory i pyłki roślin).

\footnotetext{
${ }^{1}$ Instytut Nauk Geologicznych, Uniwersytet Wrocławski, ul. Cybulskiego 30, 50-204 Wrocław; jolanta.muszer@uwr.edu.pl.

${ }^{2}$ Wydział Nauk o Ziemi i Kształtowania Środowiska, Uniwersytet Wrocławski, ul. Kuźnicza 35, 50-138 Wrocław.
} 
Kopalne dowody na interakcje między roślinami a stawonogami w paleozoiku są w przeważającej części reprezentowane przez skamieniałości śladowe, w mniejszym stopniu objawiają się poprzez charakterystyczne cechy anatomiczne budowy roślin i zwierząt, odstraszające substancje chemiczne wytwarzane przez rośliny oraz niektóre dowody reprodukcji zwierząt. Skamieniałości śladowe, czyli wszelkie świadectwa aktywności zwierzęcej w zapisie kopalnym, informują o biologii, ekologii i trybie życia wymarłych zwierząt. Jednak nie wszystkie z nich dostarczają bezpośrednich dowodów na interakcje zwierząt $\mathrm{z}$ roślinami. Chcąc ułatwić identyfikację śladów wprowadzono liczne klasyfikacje oparte np. na takich kategoriach, jak etologia, środowisko życia, morfologia czy lokalizacja śladów na organizmie rośliny. Klasyfikacje te podsumowuje m.in. Genise (2017).

Najczęściej są stosowane klasyfikacje etologiczne, czyli uwzględniające sposób zachowania się zwierząt. Seilacher (1953) wyróżnił pięć głównych grup: repichnia ślady lokomocji, cubichnia - ślady spoczynku, fodinichnia - ślady konsumpcji, domichnia - struktury mieszkalne, pascichnia - ślady konsumpcji organizmów spasających. W ostatnich kilku dekadach opisano wiele nowych kategorii etologicznych (np. Frey, 1973; Ekdale i in., 1984; Ekdale 1985; Frey, Pemberton, 1985; Bromley, 1996; Seilacher, 2007; Vallon i in., 2013, 2016). Wśród śladów zachowań zwierząt uwiecznionych na roślinach należy wymienić: calichnia (ślady rozmnażania, gniazda; Genise, Bown, 1994), xylichnia (ślady drążenia w drewnie; Genise, 1995), będące subkategorią fodinichnia oraz pupichnia (komory do przepoczwarczenia się owadów; Genise i in., 2007). Vallon i in. (2015) zaliczają pupichnia do ecdysichnia (śladów linienia).

W zależności od lokalizacji skamieniałości śladowych Vialov (1968) zaproponował terminy bioexoglyphia, dla śladów rozmieszczonych na powierzchni struktury oraz bioendoglyphia, dla śladów usytuowanych wewnątrz struktury, jednak nie są one powszechnie stosowane. Scott i in. (1992) wśród kopalnych dowodów interakcji wydzielili następujące typy: konsumpcję (zranienia, konsumpcję liści, włoski czuciowe na organach roślin, drążenia, minowanie liści, koprolity, zawartości jelit), schronienie (galasy), transport i reprodukcję (roznoszenie nasion i spor, zapylanie, składanie jaj). Propozycję podziałów skamieniałości śladowych owadów przedstawił także Zherikhin (2003). Opierają się one na różnych kryteriach, np. morfologii, środowisku, etologii, lokalizacji śladów w obrębie roślin. Ze względu na dosyć skomplikowaną terminologię i złożoność nie są w powszechnym użyciu.

Inną klasyfikację kopalnych dowodów interakcji zaproponował Labandeira $(2002 ; 2006 a)$. Wyróżnił on 6 głównych typów dowodów, zachowanych w postaci:

1) reprodukcyjnych i wegetatywnych części roślinnych, które zawierają elementy mające zachęcić do zapylania, bądź struktury mające odstraszyć i zniechęcić roślinożerców do konsumpcji;

2) śladów aktywności zwierzęcej, w postaci uszkodzeń powstałych na drodze żerowania (np. dziury, ślady ugryzień i drążeń, galasy);

3) koprolitów (skamieniałych odchodów dostarczających informacji na temat diety ówczesnych roślinożerców);
4) zawartości jelit (znajdowane w nich ślady nasion, cewek, skórek czy włosków roślinnych umożliwiają odtworzenie diety roślinożercy);

5) pozostałości aparatów gębowych (wskazują na morfologię tych aparatów u poszczególnych organizmów zwierzęcych);

6) śladów składania jaj (sposoby składania jaj i reprodukcji zwierząt).

W klasyfikacji tej tylko koprolity, ślady uszkodzeń na drodze żerowania i zawartości jelit reprezentują skamieniałości śladowe. Oznacza to, że dotychczasowe klasyfikacje dowodów na interakcje roślin i zwierząt nie obejmuja wszystkich kategorii i wymagają nowego ujęcia.

\section{PROPOZYCJA NOWEJ \\ KLASYFIKACJI DOWODÓW INTERAKCJI ROŚLIN I ZWIERZĄT}

Autorki artykułu proponują wprowadzić nową klasyfikację dowodów interakcji między roślinami a stawonogami w paleozoiku (tab. 1), opierającą się na funkcji, jaką pełni roślina, tj. pokarmu, pokarmu i/lub miejsca schronienia, miejsca schronienia, oraz reakcji rośliny (obronnej lub oferowania wzajemnych korzyści). Do każdej z wyszczególnionych funkcji i reakcji rośliny przypisano grupy dowodów i dowody. Te dowody, które reprezentują skamieniałości śladowe, oznaczono gwiazdką. Dla poszczególnych dowodów podano wybrane przykłady z literatury (tab. 2).

Gdy roślina stanowiła wyłącznie pokarm stawonoga, dowody na interakcje można zaobserwować w postaci: uszkodzeń na powierzchni roślin (zranienia, obgryzanie krawędzi, dziurawienie i szkieletyzację liści, przekłuwanie i ssanie, konsumpcję nasion i spor), morfologii aparatów gębowych stawonogów (przystosowane do przebijania i ssania), koprolitów (homogeniczne, heterogeniczne, amorficzne) oraz zawartości jelit (kololity). Roślina mogła też pełnić równocześnie funkcję pokarmu oraz miejsca schronienia, przy czym czasami trudno rozdzielić te funkcje. Świadczą o tym uszkodzenia wewnątrz roślin (jamki, tunele, galerie, drażenia z koprolitami, minowanie liści) oraz reakcja tkanki roślin (galasy). Gdy roślina stanowiła schronienie dla stawonogów, objawiało się to w postaci: składania jaj (endofityczne lub epifityczne), miejsc, w których dochodziło do przepoczwarczenia (komory do przepoczwarczenia) oraz kamuflażu (mimikra). Czasami roślina broniła się przed konsumpcja (reakcja obronna) wytwarzając odstraszające organy (np. włoski czuciowe, kolce, ciernie) lub substancje chemiczne (np. fitolity - ciałka krystaliczne, żywice zachowane w osadach paleozoicznych jako rezynit). Rośliny mogły też korzystać z obecności na nich stawonogów równocześnie oferując im pokarm, gdy podczas konsumpcji spor dochodziło do ich transportu oraz zapylania. Dowodami są wówczas aparaty gębowe przystosowane do konsumpcji spor.

\section{EKSPANSJA ROŚLINOŻERNYCH STAWONOGÓW A ETAPY ROZWOJU INTERAKCJI ROŚLIN I STAWONOGÓW W PALEOZOIKU}

Zagadnienie wczesnej kolonizacji lądów oraz ekspansji stawonogów w paleozoiku było różnie interpretowane, niekiedy nawet przez tego samego autora (np. Labandeira 
Tab. 1. Propozycja klasyfikacji paleozoicznych dowodów interakcji między roślinami a stawonogami ze względu na funkcję lub reakcję rośliny

Tab. 1. Proposition of a classification of the Paleozoic evidences of plant-arthropod interaction due to the function or reaction of the plant

\begin{tabular}{|c|c|c|}
\hline $\begin{array}{l}\text { Funkcja i/lub reakcja rośliny } \\
\text { Plant function and/or reaction }\end{array}$ & $\begin{array}{l}\text { Grupy dowodów } \\
\text { Groups of evidences }\end{array}$ & $\begin{array}{l}\text { Dowody } \\
\text { Evidences }\end{array}$ \\
\hline \multirow{11}{*}{$\begin{array}{l}\text { Pokarm } \\
\text { Food }\end{array}$} & \multirow{6}{*}{$\begin{array}{l}\text { Uszkodzenia na powierzchni roślin* } \\
\text { Traces of damage on the plant surface* }\end{array}$} & $\begin{array}{l}\text { zranienia* } \\
\text { wounding* }\end{array}$ \\
\hline & & $\begin{array}{l}\text { obgryzanie krawędzi* } \\
\text { margin feeding* }\end{array}$ \\
\hline & & $\begin{array}{l}\text { dziurawienie* } \\
\text { hole feeding* }\end{array}$ \\
\hline & & $\begin{array}{l}\text { szkieletyzacja* } \\
\text { skeletonization* }\end{array}$ \\
\hline & & $\begin{array}{l}\text { przekłuwanie i ssanie* } \\
\text { piercing and sucking* }\end{array}$ \\
\hline & & $\begin{array}{l}\text { konsumpcja nasion i spor* } \\
\text { seed and spore predation* }\end{array}$ \\
\hline & $\begin{array}{l}\text { Morfologia aparatów gębowych zwierząt } \\
\text { Morphology of animals mouthparts }\end{array}$ & $\begin{array}{l}\text { aparaty gębowe przystosowane do ssania } \\
\text { mouthparts adapted for sucking }\end{array}$ \\
\hline & \multirow{3}{*}{$\begin{array}{l}\text { Koprolity, w tym mikrokoprolity* } \\
\text { Coprolites and microcoprolites } *\end{array}$} & $\begin{array}{l}\text { typ A (homogeniczne)* } \\
\text { type A (homogenic)* }\end{array}$ \\
\hline & & $\begin{array}{l}\text { typ B (heterogeniczne)* } \\
\text { type B (heterogenic)* }\end{array}$ \\
\hline & & $\begin{array}{l}\text { typ C (amorficzne)* } \\
\text { type C (amorphic*) }\end{array}$ \\
\hline & $\begin{array}{l}\text { Zawartość jelit* } \\
\text { Gut contents* }\end{array}$ & $\begin{array}{l}\text { kololity* } \\
\text { kololites* }\end{array}$ \\
\hline \multirow{4}{*}{$\begin{array}{l}\text { Pokarm i/lub miejsce schronienia } \\
\text { Food and/or place of shelter }\end{array}$} & \multirow{3}{*}{$\begin{array}{l}\text { Uszkodzenia wewnątrz roślin* } \\
\text { Traces of damage inside the plants* }\end{array}$} & $\begin{array}{l}\text { jamki, tunele, galerie* } \\
\text { pits, tunnels, galleries* }\end{array}$ \\
\hline & & $\begin{array}{l}\text { drążenia z koprolitami* } \\
\text { borings with coprolites } *\end{array}$ \\
\hline & & $\begin{array}{l}\text { minowanie liści* } \\
\text { leaf mining* }\end{array}$ \\
\hline & $\begin{array}{l}\text { Reakcja tkanki roślin*? } \\
\text { Plant reaction tissue*? }\end{array}$ & $\begin{array}{l}\text { galasy*? } \\
\text { galls*? }\end{array}$ \\
\hline \multirow{4}{*}{$\begin{array}{l}\text { Miejsce schronienia } \\
\text { Place of shelter }\end{array}$} & \multirow{2}{*}{$\begin{array}{l}\text { Składanie jaj } \\
\text { Oviposition }\end{array}$} & $\begin{array}{l}\text { endofityczne } \\
\text { endophitic }\end{array}$ \\
\hline & & $\begin{array}{l}\text { epifityczne } \\
\text { epiphitic }\end{array}$ \\
\hline & $\begin{array}{l}\text { Miejsca do przepoczwarczenia* } \\
\text { Places for pupation* }\end{array}$ & $\begin{array}{l}\text { komory do przepoczwarczenia* } \\
\text { pupation chambers } *\end{array}$ \\
\hline & $\begin{array}{l}\text { Kamuflaż } \\
\text { Camouflage }\end{array}$ & $\begin{array}{l}\text { mimikra } \\
\text { mimicry }\end{array}$ \\
\hline \multirow{4}{*}{$\begin{array}{l}\text { Reakcja obronna } \\
\text { Defensive reaction }\end{array}$} & \multirow{2}{*}{$\begin{array}{l}\text { Odstraszające wegetatywne części roślin (obrona fizyczna) } \\
\text { Deterrent vegetative parts of plants (physical protection) }\end{array}$} & $\begin{array}{l}\text { włoski czuciowe } \\
\text { touch-sensitive trichomes }\end{array}$ \\
\hline & & $\begin{array}{l}\text { kolce ciernie } \\
\text { prickles, thorns }\end{array}$ \\
\hline & \multirow{2}{*}{$\begin{array}{l}\text { Chemiczne mechanizmy obronne } \\
\text { Chemical defences }\end{array}$} & $\begin{array}{l}\text { fitolity } \\
\text { phytoliths }\end{array}$ \\
\hline & & $\begin{array}{l}\text { żywice (rezynit) } \\
\text { resin (resinite) }\end{array}$ \\
\hline $\begin{array}{l}\text { Oferowanie wzajemnych korzyści } \\
\text { Offering mutual benefits }\end{array}$ & $\begin{array}{l}\text { Konsumpcja spor oraz transport i zapylanie } \\
\text { Palynivory, transport and pollinating }\end{array}$ & $\begin{array}{l}\text { aparaty gębowe do konsumpcji spor } \\
\text { mouth appliances adapter to palynivory }\end{array}$ \\
\hline
\end{tabular}

* skamieniałości śladowe / trace fossils; *? częściowo skamieniałości śladowe / partly trace fossils

2006a, b, 2007). Labandeira (2006a, b, 2007) wyróżnia dwa etapy ekspansji roślinożernych stawonogów w paleozoiku. Etap pierwszy, który trwał od późnego syluru (pridol) do późnego dewonu, cechuje się pojawieniem najwcześniejszych roślin lądowych o wykształconych wiązkach przewodzących oraz zapisem pierwszych interakcji pomiędzy roślinami a stawonogami. Wśród stawonogów lądowych, reprezentowanych przez roztocza i wije, w mniejszym stopniu owady bezskrzydłe i prawdopodobnie prawdziwe owady, dominowali detrytusożercy i roślinożercy (Labandeira, 2006b). Udokumentowano trzy funkcjonalne grupy żywieniowe (FFGs - functional feeding groups): 1) konsumpcję spor, sporangiów oraz zewnętrznych fragmentów roślin, 2) przekłuwanie i ssanie oraz 3) mikrodrążenia w miękiszu łodyg (Labandeira, Phillips, 1996a; Labandeira, 2006b). Koprolity pochodzące $\mathrm{z}$ tego przedziału czasowe- 
Tab. 2. Wybrane pozycje literatury przedstawiające dowody na interakcje roślin i stawonogów w paleozoiku Tab. 2. Selected papers presenting evidences of plant-arthropod interaction in the Paleozoic

\begin{tabular}{|c|c|}
\hline $\begin{array}{l}\text { Dowody } \\
\text { Evidences }\end{array}$ & $\begin{array}{l}\text { Przykłady z literatury } \\
\text { Examples from literature }\end{array}$ \\
\hline Zranienia / Wounding & Kevan i in., 1975; Banks, 1981; Scott i in., 1992 \\
\hline Obgryzanie krawędzi / Margin feeding & $\begin{array}{l}\text { Scott i in., 1992; Slater i in., 2012; Jarzembowski, 2012; Labandeira i in., 2014; } \\
\text { Pinheiro i in., } 2015\end{array}$ \\
\hline Dziurawienie / Hole feeding & $\begin{array}{l}\text { Trout i in., 2000; Labandeira, Allen, 2007; Slater i in., 2012; Labandeira i in., 2014; } \\
\text { Pinheiro i in., } 2015\end{array}$ \\
\hline Szkieletyzacja / Skeletonization & Beck, Labandeira, 1998; Labandeira, Allen, 2007 \\
\hline PrzekłUwanie i ssanie / Piercing and sucking & $\begin{array}{l}\text { Scott, Taylor, 1983; Scott i in., 1992; Labandeira, Philips, 1996a; Slater i in., 2012; } \\
\text { Schachat i in., 2014; Bernardi i in., } 2017\end{array}$ \\
\hline Konsumpcja nasion / Seed predation & $\begin{array}{l}\text { Sharov, 1973; Jennings, 1974; Scott, Taylor, 1983; Hilton i in., 2001, 2002; } \\
\text { Labandeira, 2006a, b }\end{array}$ \\
\hline $\begin{array}{l}\text { Aparaty gębowe przystosowane do ssania } \\
\text { Mouthparts adapted for sucking }\end{array}$ & Labandeira, Sepkoski, 1993; Labandeira, Phillips, 1996b; Labandeira, 1997 \\
\hline $\begin{array}{l}\text { Koprolity, w tym mikrokoprolity } \\
\text { Coprolites and microcoprolites }\end{array}$ & $\begin{array}{l}\text { Scott, 1977; Baxendale, 1979; Taylor, Scott, 1983; DiMichele, Phillips, 1994; } \\
\text { Edwards i in., 1995, 2012; Labandeira, 1998; Habgood i in., 2004; Slater i in., 2012; } \\
\text { Falcon-Lang i in., 2015 }\end{array}$ \\
\hline Zawartość jelit / Gut contents & Scott, Taylor, 1983; Scott i in. 1985; Kukalová-Peck, 1987; Labandeira, 1998, 2006a \\
\hline Jamki, tunele, galerie / Pits, tunnels, galleries & \multirow{2}{*}{$\begin{array}{l}\text { Kevan i in., 1975; Cichan, Taylor, 1982; Labandeira, 1998, 2001; Feng i in., 2010; } \\
\text { Slater i in., 2012; Muszer, Uglik, 2013; Slater, 2014; Falcon-Lang i in., } 2015\end{array}$} \\
\hline Drążenia z koprolitami / Borings with coprolites & \\
\hline Minowanie liści / Leaf mining & Müller, 1982; Scott i in., 1992; Labandeira, 2002; Labandeira, Allen, 2007 \\
\hline Galasy / Galls & $\begin{array}{l}\text { Amerom, 1973; Labandeira, Phillips, 1996b; Labandeira, Allen, 2007; Srivastava, 2007; } \\
\text { Labandeira, 2011; Slater i in., 2012; Stull i in., 2013; Labandeira i in., 2014; } \\
\text { Bernardi i in., 2017 }\end{array}$ \\
\hline Składanie jaj / Oviposition & $\begin{array}{l}\text { Carpenter, 1971; Béthoux i in., 2004; Labandeira, 2006a; Labandeira, Currano, 2013; } \\
\text { Laaß, Hoff, } 2015\end{array}$ \\
\hline Komory do przepoczwarczenia / Pupation chambers & Tapanila, Roberts, 2012 (późny paleozoik?); Mouro i in., 2016 \\
\hline Mimikra / Mimicry & Fisher, 1979; Taylor, Scott, 1983; Garrouste i in., 2016 \\
\hline Włoski czuciowe / Touch-sensitive trichomes & Edwards, Wratten, 1980; Scott, Taylor, 1983; Krings i in., 2002 \\
\hline Kolce, ciernie / Prickles, thorns & Rayner, 1983; Edwards i in., 2016; Liu i in., 2017 \\
\hline Fitolity / Phytoliths & Carter, 1999; Taylor i in., 2009; Strömberg i in., 2016 \\
\hline Żywice (rezynit) / Resin (resinite) & Taylor i in., 2009; Langenheim, 2003; Versteegh, Riboulleau, 2010 \\
\hline $\begin{array}{l}\text { Aparaty gębowe do konsumpcji spor } \\
\text { Mouth appliances adapter to palynivory }\end{array}$ & Carpenter, 1969; Labandeira, 2006a \\
\hline
\end{tabular}

go zawierają spory, co jest dowodem na ich konsumpcję (Edwards i in., 1995).

Od późnego dewonu do środkowego mississipu kopalny zapis organizmów lądowych jest bardzo słaby, szczególnie czworonogów, od nazwiska odkrywcy nazwany luką Romera (patrz np. Ward i in., 2006). Luka Romera jest najprawdopodobniej luką pozorną, która wynika z niekompletności zapisu paleontologicznego (np. Smithson i in., 2012). W tym interwale czasowym występuje też przerwa w zapisie kopalnym stawonogów oraz interakcji roślin ze stawonogami (Labandeira, 2006a, b, 2007). Drugi etap kolonizacji lądów przez roślinożerne stawonogi trwał, według tego autora, od końca środkowego mississipu do końca permu. Początkowo w zbiorowiskach roślin dominowały drzewiaste paprociowe, skrzypowe i widłakowe oraz pierwsi przedstawiciele nagonasiennych (np. kordaity, iglaste, miłorzębowe), natomiast od środkowego permu zaczęły przeważać nagonasienne (era mezofityczna). W tak zróżnicowanym środowisku nastąpiła ekspansja roślinożerców oraz pojawiło się wiele nowych kladów stawonogów, np. owady pierwotnoskrzydlate, ważki i chrząszcze. Spośród dowodów na interakcje dominuje konsumpcja żywych tkanek roślinnych (liści, nasion, korzeni, drewna) i pojawiły się galasy. Labandeira (2006 a, b) stwierdza, że ustabilizowały się wówczas główne grupy FFGs.

Kolejne dwa etapy ekspansji roślinożernych stawonogów trwały od triasu do wczesnej kredy oraz od wczesnej kredy do czasów współczesnych i charakteryzowały się występowaniem siedmiu funkcjonalnych grup żywieniowych (Labandeira 2006a, b).

Nowe doniesienia paleontologiczne (np. Slater i in., 2012; Stull i in., 2013; Labandeira i in., 2014; Laaß, Hoff, 2015) wskazują na konieczność rewizji poglądów na temat pojawiania się poszczególnych dowodów interakcji roślin i stawonogów w zapisie kopalnym oraz etapów ich rozwoju w paleozoiku (ryc. 1). Pierwsza faza rozwoju interakcji, która trwała od późnego syluru do środkowego mississipu, obejmuje pierwszą fazę ekspansji roślinożernych stawonogów wraz z luką Romera. Cechuje się stopniowym pojawianiem się pierwszych dowodów interakcji, niezbyt licznie występujących w zapisie kopalnym. W osadach górnego syluru zostały udokumentowane najstarsze dowody na interakcje, tj. koprolity, ślady zranień i konsumpcji spor (np. Edwards i in., 1995; Slater, 2014), świadczące o tym, że rośliny stanowiły pokarm stawonogów. Z dolnego dewonu znane są kolejne świadectwa interakcji: przekłuwanie i ssanie (np. Labandeira, 2007, 2013), drążenia w drewnie 
(np. Kevan i in., 1975) oraz pierwsze reakcje obronne, tj. kolce i ciernie (np. Edwards i in., 2016). Pod koniec środkowego dewonu pojawiły się galasy, obgryzanie krawędzi i dziurawienie liści (Labandeira i in., 2014). W późnym dewonie rośliny wykształciły chemiczne mechanizmy obronne, tzn. fitolity oraz żywice (rezynit), prawdopodobnie w reakcji na coraz intensywniejszą konsumpcję (Taylor $\mathrm{i}$ in., 2009). Natomiast od mississipu znane są najstarsze ślady konsumpcji nasion (Labandeira, 2006a, b).

Wyraźna zmiana nastąiła pod koniec środkowego mississipu, kiedy to rozpoczęła się druga faza rozwoju interakcji roślin i stawonogów, która trwała do końca permu. Dotychczasowe dowody na interakcje znane z pierwszej fazy stały się liczniejsze w zapisie skalnym, ponadto stopniowo pojawiły się nowe dowody, a rośliny częściej były wykorzystywane przez stawonogi jako miejsce schronienia (ryc. 1). Od początku pensylwanu występują ślady składania jaj (Labandeira, 2006a; Laaß, Hoff, 2015), włoski czuciowe na powierzchniach roślin (np. Krings i in., 2002) oraz kamuflaż (np. Taylor, Scott, 1983). Również w pensylwanie odnotowano występowanie minowania liści, zjadania korzeni oraz zapis zawartości jelit (np. Scott i in., 1985, 1992; Labandeira, 2002, 2006a). Od permu znana jest szkieletyzacja liści (Labandeira, Allen, 2007) i istnieje duże prawdopodobieństwo znalezienia komór do przepoczwarczania, gdyż z permu znani są przedstawiciele owadów rozmnażających się w ten sposób (Tapanila, Roberts, 2012).

\section{PODSUMOWANIE}

Zaproponowano nową klasyfikację dowodów na interakcje między roślinami a stawonogami $\mathrm{w}$ paleozoiku na podstawie funkcji, jaką pełniły rośliny oraz ich reakcji na konsumpcję (tab. 1). Stanowi ona próbę połączenia klasyfikacji według Scotta i in. (1992) oraz Labandeiry (2002, 2006a). Rośliny pełniły funkcję pokarmu (ryc. 2 - patrz str. 520), miejsca schronienia, jednocześnie pokarmu i miejsca schronienia, a także broniły się przed konsumpcją (reakcja obronna fizyczna lub chemiczna) lub oferowały wzajemne korzyści. Pierwsze cztery kategorie w przeważającej większości można zaliczyć do oddziaływań antagonistycznych, ponieważ rośliny ponosiły szkody na skutek oddziaływań stawonogów. Ostatnia kategoria, mutualistyczna, należy do oddziaływań nieantagonistycznych.

Spośród grup dowodów na interakcje pomiędzy zwierzętami a roślinami do skamieniałości śladowych zaliczamy: uszkodzenia na powierzchni i wewnątrz roślin, koprolity, zawartość jelit, miejsca do przepoczwarczenia oraz częściowo reakcję tkanek roślin (galasy). Pozostałe grupy dowodów są reprezentowane przez elementy budowy roślin i zwierząt (np. odstraszające części roślin, aparaty gębowe stawonogów przystosowane do przebijania tkanek roślinnych, konsumpcji spor lub ssania), odstraszające substancje chemiczne wytwarzane przez rośliny, jaja stawonogów składane na roślinach oraz kamuflaż.

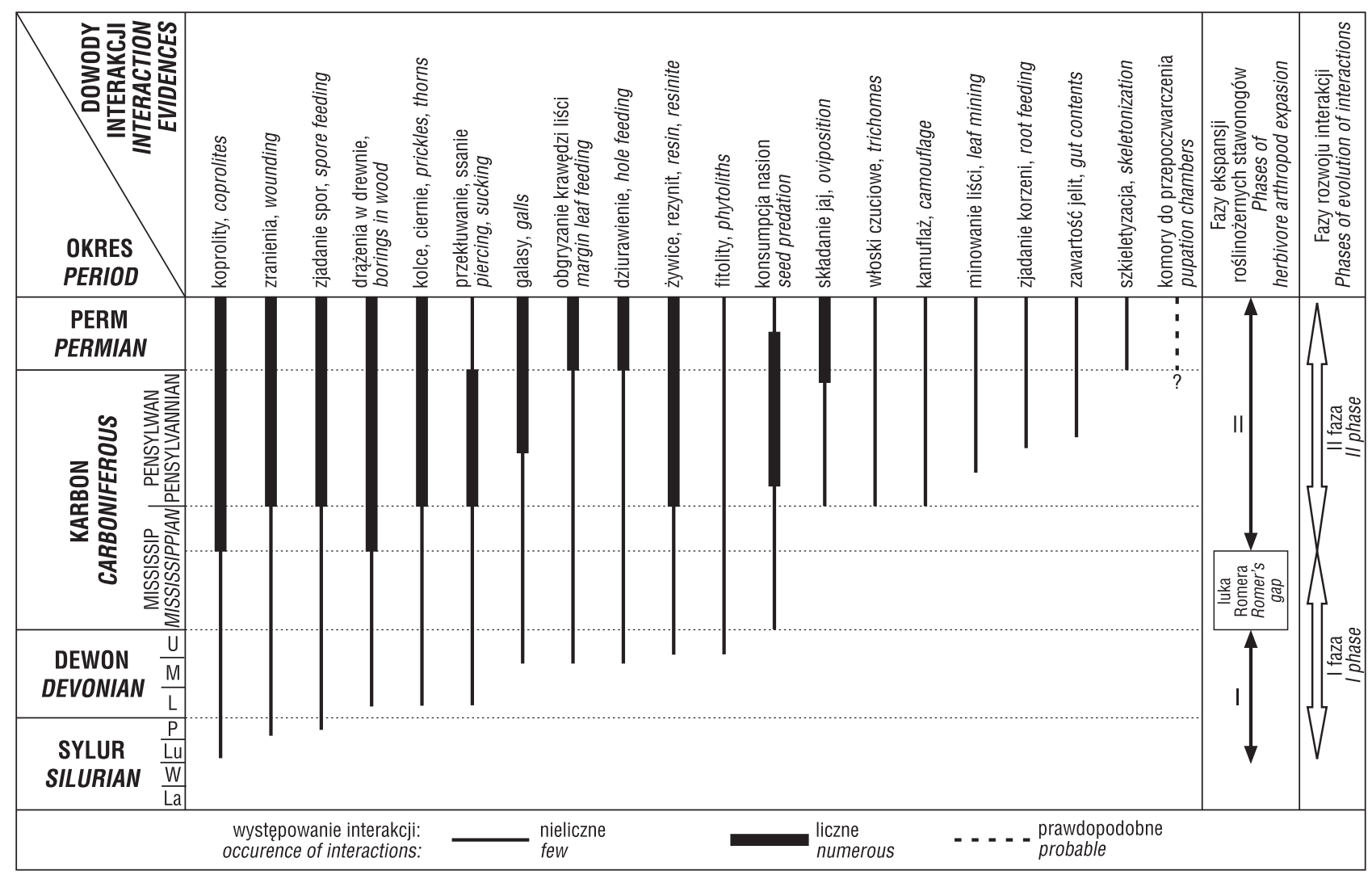

Ryc. 1. Pojawianie się dowodów na interakcje roślin i stawonogów roślinożernych w paleozoiku (na podstawie: Scott i in., 1992; Carter, 1999; Labandeira, 1998, 2001, 2006 a, b, 2007, 2013; Labandeira, Allen, 2007; Taylor i in., 2009; Slater i in., 2012; Stull i in., 2013; Labandeira i in., 2014; Laaß, Hoff, 2015) oraz fazy ekspansji roślinożernych stawonogów (na podstawie Labandeira, 2006a, b, 2007) i fazy rozwoju interakcji między roślinami a stawonogami

Fig. 1. Occurrence of individual evidences of plant-arthropod interaction in the Palaeozoic (based on: Scott i in., 1992; Carter, 1999; Labandeira, 1998, 2001, 2006 a, b, 2007, 2013; Labandeira, Allen, 2007; Taylor i in., 2009; Slater i in., 2012; Stull i in., 2013; Labandeira $\mathrm{i}$ in., 2014; Laaß, Hoff, 2015), phases of herbivore arthropod expansion (based on Labandeira, 2006a, b, 2007) and phases of evolution of plant-arthropod interactions 
Dowody na interakcje pojawiały się stopniowo (ryc. 1). $\mathrm{Na}$ podstawie ich frekwencji $\mathrm{w}$ zapisie kopalnym oraz zasięgów stratygraficznych wyróżniono w paleozoiku dwie fazy rozwoju interakcji roślin i stawonogów, które skorelowano $\mathrm{z}$ fazami ekspansji roślinożernych stawonogów (patrz Labandeira 2006a, b, 2007).

Pierwsza faza rozwoju interakcji trwała od późnego syluru do końca środkowego mississipu, druga faza - od późnego mississipu do końca permu. W pierwszej fazie rozwoju interakcji przeważały dowody świadczące o pokarmowej funkcji roślin (koprolity, zranienia, konsumpcja spor, przekłuwanie i ssanie, obgryzanie krawędzi liści, dziurawienie, konsumpcja nasion) oraz obronnej reakcji roślin (kolce, ciernie, galasy, fitolity, rezynit). Drążenia w drewnie świadczą, że rośliny oprócz funkcji pokarmowej, mogły też pełnić rolę schronienia.

W drugiej fazie rozwoju interakcji oprócz wcześniejszych dowodów pojawiają się nowe, świadczące o tym, że rośliny były powszechnym miejscem schronienia (składanie jaj, kamuflaż, minowanie liści i prawdopodobnie komory do przepoczwarczenia). Pojawiają się też nowe dowody na funkcje pokarmowe (szkieletyzacja liści, zjadanie korzeni, zawartość jelit) i obronne (włoski czuciowe) roślin. Poznanie dowodów i zmian interakcji między roślinami a stawonogami w paleozoiku pozwoli na lepsze zrozumienie wczesnej ewolucji ekosystemów lądowych.

Praca została sfinansowana z grantu UWr nr 0401/0157/17.

\section{LITERATURA}

AMEROM H.W.J. VAN. 1973 - Gibt es Cecidien im Karbon bei Calamiten und Asterophylliten? [W:] Josten, K.-H. (ed.) Compte Rendu Septiéme Congrés International de Stratigraphie et de Géologie du Carbonifére. Krefeld, Germany, Geologisches Landesamt Nordrhein-Westfalen: 63-83. BANKS H.P. 1981 - Peridermal activity (wound repair) in an Early Devonian (Emsian) trimerophyte from Gaspé Peninsula, Canada. The Palaeobotanist, 28-29: 20-25.

BARNARD P. 1974 - Little evidence for Palaeozoic arthropod and plant interaction. Nature, 249: 615-616.

BAXENDALE R.W. 1979 - Plant-bearing coprolites from North American Pennsylvanian coal balls. Palaeontology, 22: 537-546.

BECK A.L., LABANDEIRA C.C. 1998 - Early Permian insect folivory on a gigantopterid-dominated riparian flora from north-central Texas. Palaeogeogr., Palaeoclim., Palaeoecol., 142: 138-173.

BERNARDI M., PETTI F.M., KUSTATSCHER E., FRANZ M., HARTKOPF-FRÖDER C., LABANDEIRA C.C., WAPPLER T., KONIJNENBURG-VAN CITTERT J.H.A., PEECOOK B.R., ANGIELCZYK K.D 2017 - Late Permian (Lopingian) terrestrial ecosystems: A global comparison with new data from the low-latitude Bletterbach Biota. Earth-Science Reviews, 175: 18-43.

BÉTHOUX O., GALTIER J., NEL A. 2004 - Earliest Evidence of Insect Endophytic Oviposition. Palaios, 19: 408-412.

BROMLEY R.G. 1996 - Trace Fossils. Biology, Taphonomy and Applications. Chapman and Hall, London: 361.

BRUES C.T. 1936 - Evidences of insect activity preserved in wood. J. Paleont., 10: 637-643.

CARPENTER F.M. 1969 - Fossil insects from Antarctica. Psyche, 76 : $418-425$.

CARPENTER F.M. 1971 - Adaptations among Palaeozoic insects. Proceedings of the North American Paleontology Convention 1969, 1: 1236-1251.

CARTER J.A. 1999 - Late Devonian, Permian and Triassic phytoliths from Antarctica. Micropaleontology, 45: 56-61.

CHALONER W.G., SCOTT A.C., STEPHENSON J. 1991 - Fossil evidence for plant arthropod interactions in the Palaeozoic and Mesozoic. Philosophical Transactions of the Royal Society B, 333: 177-186.

CICHAN M.A., TAYLOR T.N. 1982 - Wood-borings in Premnoxylon: Plant-animal interactions in the Carboniferous. Palaeogeogr., Palaeoclim., Palaeoecol., 39: 123-127.

DIMICHELE W.A., PHILLIPS T.L. 1994 - Paleobotanical and paleoecological constraints on models of peat formation in the Late Carboniferous of Euramerica. Palaeogeogr., Palaeoclim., Palaeoecol., 106: 39-90.
EDWARDS P.J., WRATTEN S.D. 1980 - Ecology of insect-plant interactions. Studies in Biology, 121

EDWARDS D., GENG B-Y., LI C-S. 2016 - New Plants from the Lower Devonian Pingyipu Group, Jiangyou County, Sichuan Province, China. Plos One 11. DOI:10.1371/journal.pone.0163549.

EDWARDS D., SELDEN P.A., RICHARDSON J.B., AXE L. 1995 Coprolites as evidence for plant-animal interaction in Siluro-Devonian terrestrial ecosystems. Nature, 377: 329-331.

EDWARDS D., SELDEN P.A., AXE L. 2012 - Selective feeding in an Early Devonian terrestrial ecosystem. Palaios, 27: 509-522.

EKDALE A.A. 1985 - Paleoecology of the marine endobenthos. Palaeogeogr., Palaeoclim., Palaeoecol., 50: 63-81.

EKDALE A.A., BROMLEY R.G., PEMBERTON S.G. 1984 - Ichnology: The use of trace fossils in sedimentology and stratigraphy. Society of Economic Paleontologists and Mineralogists. Short Course, 15: 317. FALCON-LANG H.J., LABANDERIA C.C., KIRK R. 2015 - Herbivorous and detritivorous arthropod trace fossils associated with subhumid vegetation in the middle Pennsylvanian of Southern Britain. Palaios, 30: 193-202.

FENG Z., WANG J., LIU L.J. 2010 - First report of oribatid mite (arthropod) borings and coprolites in Permian woods from the Helan Mountains of northern China. Palaeogeogr., Palaeoclim., Palaeoecol., 288: 54-60. FISHER D.C. 1979 - Evidence of subaerial activity of Euproops danae (Merostomata, Xiphosurida). [W:] Nitecki M.H. (red.) Mazon Creek Fossils, Academic Press, New York: 379-448.

FOJCIK B. 2014 - Na początku były mszaki - czyli jak to było z wyjściem na ląd. Kosmos, 63 (3): 429.

FREY R.W. 1973 - Concepts in the study of biogenic sedimentary structures. J. Sedimen. Petrol., 43: 6-19.

FREY R.W., PEMBERTON S.G. 1985 - Biogenic structures in outcrops and cores. I. Approches to ichnology. Bull. of Canadian Petrol. Geol., 33: $72-115$.

GARROUSTE R., HUGEL S., JACQUELIN L., ROSTAN P., STEYER J.S., DESUTTER-GRANDCOLAS L., NEL A. 2016 - Insect mimicry of plants dates back to the Permian. Nature Communications, 7: 1-2.

GENISE J.F. 1995 - Upper Cretaceous trace fossils in permineralized plant remains from Patagonia, Argentina. Ichnos, 3: 287-299.

GENISE J.F. 2017 - Ichnoentomology: Insect traces in soils and paleosols. Topics in Geobiol., 37. Springer.

GENISE J.F., BOWN T.M. 1994 - New Miocene scarabeid and hymenopterous nests and Early Miocene (Santacrucian) paleoenvironment, Patagonian Argentina. Ichnos, 3: 107-117.

GENISE J.F., MELCHOR R.N., BELOSI E.S., GONZÁLES M.G., KRAUSE M. 2007 - New pupation chambers (pupichnia) from the Upper Cretaceous of Patagonia, Argentina. Cretaceous Res., 28: 545-559.

GENSEL P.G., EDWARDS D. (eds) 2001 - Plants Invade the Land. Evolutionary, Environmental Perspectives. Columbia University Press, New York, 304

HABGOOD K.S., HASS H., KERP H. 2004 - Evidence for an early terrestial food web: coprolites from the Early Devonian Rhynie chert. Transactions oft he Royal Society of Edinburgh, Earth Sciences, 94: 371-389. HERING E.M. 1951 - Biology of the leaf miners. W. Junk, The Hague, The Netherlands, 420 .

HILTON J., ROTHWELL G.W., LI S.-S., WANG S.-J., GALTIER J. 2001 - Permineralized cardiocarpalean ovules in wetland vegetation from Early Permian volcaniclastic sediments of China. Palaeont, 44: $811-825$.

HILTON J., WANG S.O.J., ZHU W.-Q.,TIAN B., GALTIER J., WEI A.-H. 2002 - Callospermarion ovules from the Early Permian of northern China: palaeofloristic and palaeogeographic significance of callistophytalean seed-ferns in the Cathaysian flora. Rev. Palaeobot. Palynol., 120: 301-314.

HUGES N.F., SMART J. 1967 - Plant-insect relationships in Palaeozoic and later time. [W:] Harland W.B. (ed.) The fossil record: A symphosium and documentation: 107-117. Geol. Soc. of London.

JARZEMBOWSKI E.A. 2012 - The oldest plant-insect interaction in Croatia: Carboniferous evidence. Geol. Croatia, 65 (3): 388-390.

JENNINGS J.R. 1974 - Lower Pennsylvanian plants of Illinois. A flora from the Pounds Sandstone Member of the Caseyville Formation. J. Paleont., 48: 459-473.

KENRICK P., CRANE P.R. 1997 - The origin and early evolution of plants on land. Nature, 389: 33-34.

KEVAN P.G., CHALONER W.G., SAVILE D.B.O. 1975 - Interrelationships of early terrestrial arthropods and plants. Palaeont., 18: 391-417. KRINGS M., TAYLOR T.N., KELLOGG D.W. 2002 - Touch-sensitive glandular trichomes: a mode of defence against herbivorous arthropods in the Carboniferous. Evolutionary Ecol. Res., 4: 779-786.

KUKALOVÁ-PECK J. 1987 - New Carboniferous Diplura, Monura and Thysanura, the hexapod ground plan, and the role of thoracic lobes in the origin of wings (Insecta). Canadian J. Zool., 65: 2327-2345. 
LAAß M., HOFF C. 2015 - The earliest evidence of damselfly-like endophytic oviposition in the fossil record. Lethaia, 48: 115-122.

LABANDERIA C.C. 1997 - Insect mouthparts: ascertaining the paleobiology of insect feeding strategies. Ann.Rev. Ecol. and Systematics, 28: 153-193.

LABANDERIA C.C. 1998 - Early history of Arthropod and vascular plant associations. Ann. Rev. Earth and Planetary Sc., 26: 329-365. LABANDERIA C.C. 2001 - Rise and diversification of insects. [W:] Briggs D.E.G., Crowther P.R. (eds.) Palaeobiology II, Blackwell Science, London: 82-88.

LABANDERIA C.C. 2002 - The history of associations between plants and animals. [W:] Herrera C.M., Pellmyr O. (eds). Plant Animal Interactions: An Evolutionary Approach. Part 1: 26-76. Blackwell Science. LABANDEIRA C.C. 2006a - Silurian to Triassic Plant and Hexapod Clades and their Associations: New Date, a Review, and Interpretations. Arthropod Systematics and Phylogeny, 64 (1): 53-86.

LABANDERIA C.C. $2006 \mathrm{~b}$ - The four phases of plant-Arthropod associations in deep time. Geologica Acta, 4 (4): 410-427.

LABANDERIA C.C. 2007 - The origin of herbivory on land: initial patterns of plant tissue consumption by arthropods. Insect Science, 14: 259-275.

LABANDEIRA C.C. 2011 - Evidence for an earliest Late Carboniferous divergence time and the early larval ecology and diversification of major Holometabola lineages. Entomologica Americana, 117 (1): 9-18.

LABANDEIRA C.C. 2013 - A paleobiologic perspective on plant-insect interactions. Current Opinion in Plant Biology, 16: 414-419.

LABANDERIA C.C., ALLEN E.F. 2007 - Minimal insect herbivory for the Lower Permian Coprolite Bone Bed site of north-central Texas, USA, and comparison to other Late Paleozoic floras. Palaeogeogr., Palaeoclim., Palaeoecol., 247: 197-219.

LABANDERIA C.C., CURRANO E.D. 2013 - The fossil record of plant-insect dynamics. Ann. Rev. Earth and Planetary Sc., 41:287-311.

LABANDERIA C.C., PHILIPS T.L. 1996a - Insect fluid-feeding on Upper Pennsylvanian tree ferns (Palaeodictyoptera, Marattiales) and the early history of the piercing-and-sucking functional feeding group. Ann. Entomolog. Soc. of America, 89: 157-183.

LABANDERIA C.C., PHILIPS T.L. 1996b - A Carboniferous petiole gall: insight into early ecologic history of the Holometabola. Proc. National Academy of Sc. USA, 93: 8470-8474.

LABANDERIA C.C., SEPKOSKI J.J. 1993 - Insect diversity in the fossil record. Science, 261: 310-315.

LABANDERIA C.C., TREMBLAY S.L, BARTOWSKI K.E, VANALLER HERNICK L. 2014 - Middle Devonian liverwort herbivory and antiherbivore defence. New Phytologist, 202: 247-258.

LANGENHEIM J.H. 2003 - Plant Resins: Chemistry, Evolution, Ecology, and Ethnobotany. Portland, Cambridge, Timber Press: 586.

LIU L., WANG D., MENG M., XUE J. 2017 - Further study of Late Devonian seed plant Cosmosperma polyloba: its reconstruction and evolutionary significance. BMC Evolutionary Biology, 17, 149. DOI 10.1186/s12862-017-0992-1.

MOURO L.D., ZATOŃ M., FERNANDES A.C.S., WAICHEL B.L. 2016 - Larval cases of caddisfly (Insecta: Trichoptera) affinity in Early Permian marine environments of Gondwana. Scientific Reports. DOI $10.1038 /$ srep 19215

MÜLLER A.H. 1982 - Über Hyponomefossiler und rezenter Insekten, erster Beitrag. Freuberger Forschungsheft C 366: 7-27.

MUSZER J., UGLIK M. 2013 - Palaeoenvironmental reconstruction of the Upper Visean Paprotnia Beds (Bardo Unit, Polish Sudetes) using ichnologicaland palaeontological data. Geol. Quart., 57 (3): 356-376.

NEEDHAM J.G., FROST S.W., TOTHILL B.H. 1928 - Leaf-mining insects. 351 pp. Baltimore, The Williams, Wilkins Company.

PINHEIRO E.R.S., GALLEGO J., IANNUZZI R., CUNEO R. 2015

First report of feeding traces in Permian Botrychiopsis leaves from Western Gondwana. Palaios, 30: 615-617.

RAYNER R.J. 1983 - New observations on Sawdonia ornata from Scotland. Earth and Environmental Science Transactions of the Royal Society of Edinburgh, 74, 2: 79-93.

SCHACHAT S.R., LABANDERIA C.C., GORDON J.. CHANEY D., LEVI S., HALTHORE M.N., ALVAERES J. 2014 - Plant-Insect Interactions from Early Permian (Kungurian) Colwell Creek Pond, North-Central Texas: The Early Spread of Herbivory in Riparian Environments. Int. J. Plant Sci.. 175 (8): 855-886.

SCOTT A.C. 1977 - Coprolites containing plant material from the Carboniferous of Britain. Palaeontology, 20: 59-68.

SCOTT A.C., TAYLOR T.N. 1983-Plant/animal interactions during the Upper Carboniferous. Botanical Rev., 49: 259-307.

SCOTT A.C., CHALONER W.G., PATERSON S. 1985 - Evidence of pteridophyte-arthropod interactions in the fossil record. Proceedings of the Royal Society of Edinburg, 86B: 133-140.

SCOTT A.C., STEPHENSON J., CHALONER W.G. 1992 - Interaction and coevolution of plants and arthropods during the Palaeozoic and Mesozoic. Philosophical Transactions of the Royal Society, B, 335: 129-165.
SEILACHER A. 1953 - Studien zur Palichnologie. I. Über die Methoden der Palichnologie. Neues Jahrb. für Geol. und Paläont., Abh., 96: 421-452.

SEILACHER A. 2007 - Trace Fossil Analysis. Springer: 226.

SHAROV A.G. 1973 - Morphological features and way of life of Paleodictyoptera. [W:] E.P. Narchuk (ed.) Problems of Insects Paleontology Lectures on the $24^{\text {th }}$ Annual Readings in Memory of N.A. Kholodkovsky, 23: 49-63. (in Russian).

SLATER B.J. 2014 - Fossil Focus: Arthropod-plant interactions. Palaeont. Online, 4 (5): 1-11.

SLATER B.J., MCLOUGHLIN S., HILTON J. 2012 - Animal-plant interactions in a Middle Permian permineralised peat of the Bainmedart Coal Measures, Prince Charles Mountains, Antarctica. Palaeogeogr., Palaeoclim., Palaeoecol., 363-364: 109-121.

SMITHSON T.R., WOOD S.P., MARSHALL J.E.A., CLACK J.A. 2012. - Earliest Carboniferous tetrapod and arthropod faunas from Scotland populate Romer's Gap. Proceedings of the National Academy of Sciences of the United States of America, 109 (12): 4532-4537.

SOUTHWOOD T.R.E. 1973 - The insect/plant relationship - an evolutionary perspective. Symposium of the Royal Entomological Society of London, 6: 3-30.

SRIVASTAVA A.K. 2007 - Fossil evidences of gall-inducing arthropod-plant interactions in the Indian subcontinent, Oriental Insects, 41: 213-222.

STOPES M.C. 1907 - A note on wounded Calamites. Annals of Botany, 21: $277-280$.

STRÖMBERG C.A.E., DI STILIO V.S., SONG Z. 2016 - Functions of phytoliths in vascular plants: an evolutionary perspective. Functional Ecology, 30: 1286-1297.

STULL G.W., LABANDERIA C.C., DIMICHELE W.A., CHANEY D.S 2013 - The "seeds" on Padgettia readi are insect galls: reassignment of the plant to Odonopteris, the gall to ovofoligallites n.gen., and the evolutionary implications thereof. J. Paleont., 87 (2): 219-221.

TAPANILA L., ROBERTS E.M. 2012 - The Earliest Evidence of Holometabolan Insect Pupation in Conifer Wood. Plos One 7(2): e31668. doi:10.1371/journal.pone. 0031668

TAYLOR T.N., HASS H., REMY W. 1992 - Devonian fungi: interactions with the green alga Paleonitella. Mycologia, 84: 901-910.

TAYLOR T.N., REMY W., HASS H., KERP H. 1995 - Fossil arbuscular mycorrhizae from the Early Devonian. Mycologia, 87: 560-573.

TAYLOR T.N., SCOTT A.C. 1983 - Interactions of Plants and Animals During the Carboniferous. BioScience, 33: 488-490

TAYLOR T.N., TAYLOR E.L., KRINGS M. 2009. Paleobotany. The Biology and Evolution of Fossil Plants. Elsevier: 1232.

TROUT M., LABANDEIRA C.C., CHAPMAN R. 2000 - Morphometric analysis of insect damage on Neuropteris and implications for Paleozoic herbivory. Geological Society of America, Abstracts with Programs, 32: A219-220.

VALLON L.H., RINDSBERG A.K., BROMLEY R.G. 2013 - An updated classification of animal behavior in substrates. In: Demircan H. (ed.) XII International Ichnofabric Workshop. Çanakkale - Dardanelles, Turkey $\left(30^{\text {th }}\right.$ June $-5^{\text {th }}$ July 2013). Abstracts: $82-85$.

VALLON L.H., RINDSBERG A.K., BROMLEY R.G. 2016 - An updated classification of animal behavior preserved in substrates. Geodinamica Acta, 28 (1-2): 5-20.

VALLON L.H., SCHWEIGERT G., BROMLEY R.G., RÖPER M, EBERT M. 2015 - Ecdysichnia - a new ethological category for trace fossils produced by moulting. Annales Societatis Geologorum Poloniae, 85 (3): $433-444$.

VERSLEEGH G.J.M., RIBOULLEAU A. 2010. An organic geochemical perspective on terrestrialization. In: Vecoli M., Clément G., Meyer-Berthaud B. (eds) The Terrestrialization Process: Modelling Complex Interactions at the Biosphere-Geosphere Interface. Geol. Soc., London, Spec. Publ., 339: 11-36.

VIALOV O. S. 1968 - Materials to classification of trace fossils and traces of activity of organisms. Paleontologichesky Sbornik, 5 (1): 125-129. (in Russian).

WARD P., LABANDEIRA C., LAURIN M., BERNER R. 2006 - Confirmation of Romer's Gap as a low oxygen interval constraining the timing of initial arthropod and vertebrate terrestrialization. Proceedings of the National Academy of Sciences of the United States of America, 103 (45): $16818-16822$

WEINER J. 2003 -Życie i ewolucja biosfery. Warszawa. Wyd. Nauk. PWN. WILF P. 2008 - Insect-damaged fossil leaves record food web response to ancient climate change and extinction. New Phytologist, 178: 486-502. ZHERIKHIN V.V. 2003 - Insect trace fossils, their diversity, classification and scientific importance. Acta Zool. Cracov., 46: 59-66.

Praca wpłynęła do redakcji $4.06 .2018 \mathrm{r}$.

Akceptowano do druku 4.08.2018 r. 
Paleozoiczne dowody na interakcje między roślinami a stawonogami (patrz str. 503)

Paleozoic evidences of interactions between plants and arthropods (see p. 503)

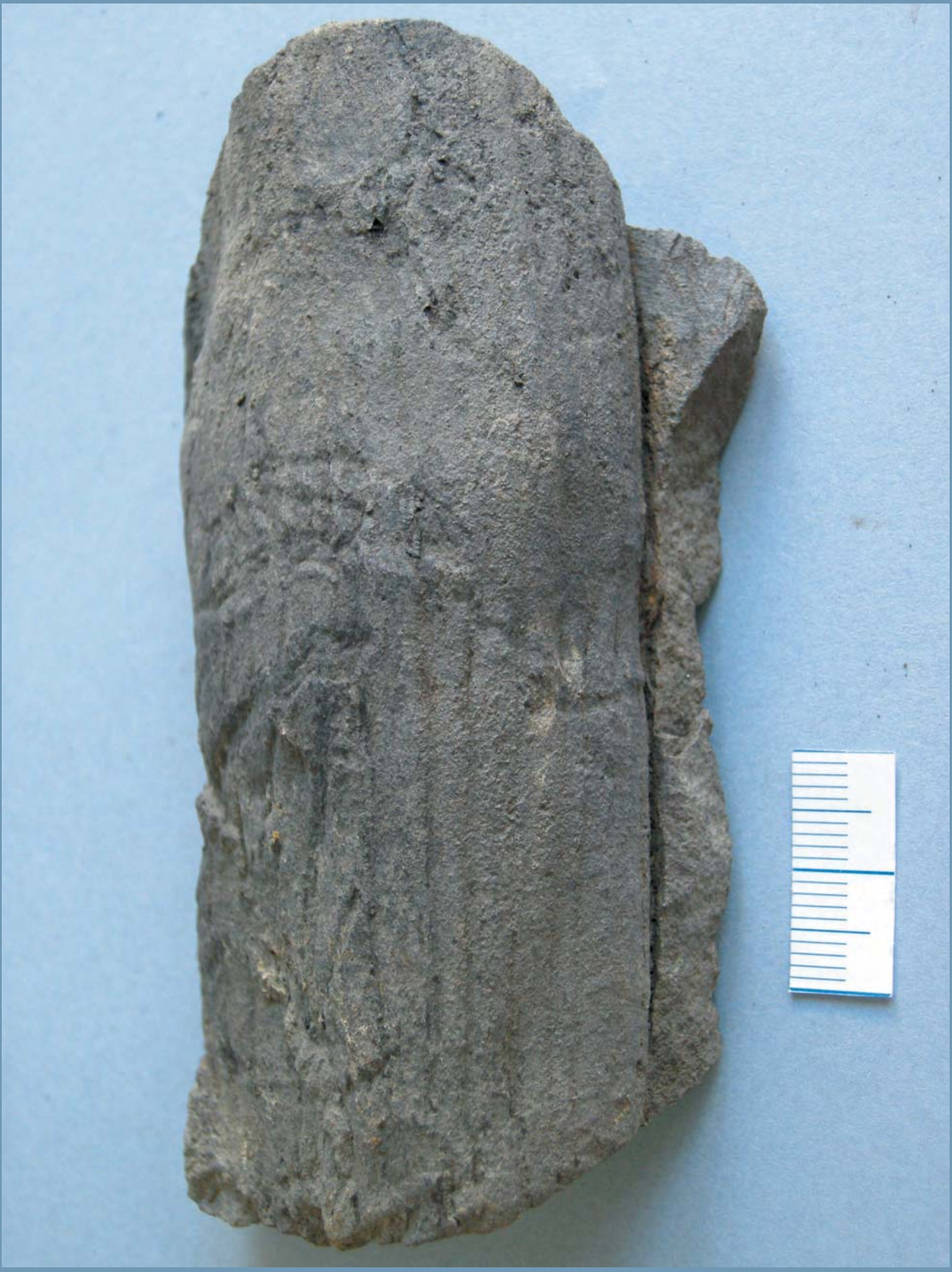

Ryc. 2. Ślady drążenia Paleobuprestis sudeticus Muszer, Uglik, 2013 w drewnie archeokalamitów, powstale na skutek żerowania stawonogów; wizen Sudety (struktura bardzka; Paprotnia)

Fig. 2. Traces of Paleobuprestis sudeticus boring Muszer, Uglik, 2013 in wood archeokalamites, incurred as a result of preying of arthropods; Visean, Sudetes Mts. (Bardo structure; Paprotnia) 